Toruń

\title{
Systemy parlamentarne wybranych państw arabskich i muzułmańskich w świetle notatki dla kierownictwa MSZ z 1972 r.
}

\footnotetext{
$\mathbf{S}$
} ystemy polityczne, a wśród nich systemy parlamentarne, stanowią ciekawe źródło inspiracji naukowej, w szczególności jeżeli dotykają one obszarów czy regionów, które są stosunkowo słabo poznane nie tylko na gruncie polskim, ale i europejskim ${ }^{1}$. Sytuacja taka dotyka także świata arabskiego i muzułmańskiego, który ze względu na swą specyfikę, często postrzegany jest przez świat Zachodu jako obszar powiązany z fundamentalizmem. W cywilizacji tej dopracowano się jednak licznych rozwiązań politycznych, ustrojowych czy publicznych, które zasługują na poznanie i głębszą anali$z_{e} e^{2}$. Europejskie Partnerstwo Śródziemnomorskie powinno sprzyjać takim inicjatywom, gdyż dzięki instytucjonalizacji życia politycznego lepiej poznaje się nie tylko stronę oddziaływań, ale i jej system aksjologiczny.

Przedmiotem niniejszego materiału jest przytoczenie dokumentu ministerialnego odnoszącego się do systemów parlamentarnych wybranych krajów arabskich i muzułmańskich oraz dokonanie jego analizy. Przedmiotowy materiał został dołączony do dokumentacji przygotowanej na posiedzenie polskiego kierownictwa Ministerstwa Spraw Zagranicznych, na którym omawiano założenia pracy resortu na 1973 r. Załącznik ten przygotowany został w Warszawie ok. 8 grudnia 1972 r. wraz z całą dokumentacją, obejmującą dwie części do dyskusji. W pierwszej omówione zostały kraje arabskie i Iran, a w drugiej państwa Czarnej Afryki. Publikowany poniżej załącznik stanowił uzupełnienie części pierwszej odnoszącej się do krajów Bliskiego Wschodu i Afryki Północnej ${ }^{3}$. Obszar ten leżał w zakresie kompetencyjnym wspomnianego Departamentu ${ }^{4}$.

${ }^{1}$ Zob. A. Antoszewski, R. Herbut, Systemy polityczne wspótczesnej Europy, Warszawa 2006; A. Antoszewski, R. Herbut, Systemy polityczne wspótczesnego świata, Gdańsk 2001; R. Balicki, Ustroje państw wspótczesnych, Wrocław 2003; M. Bankowicz, J. Tkaczyński, Oblicza wspótczesnego państwa, Toruń 2003; J. Baszkiewicz, Powszechna historia ustrojów państwowych, Gdańsk 1998; P. Deszczyński, K. Gołata, Demokratyczne systemy i doktryny polityczne, Poznań 2003; M. Gulczyński, Panorama systemów politycznych świata, Warszawa 2004; J. Knopek (oprac.), Współczesne systemy polityczne w wypisach, Bydgoszcz 2001; P. Sarnecki, Ustroje konstytucyjne państw wspótczesnych, Kraków 2003; Współczesne systemy polityczne, red. M. Żmigrodzki, B. Dziemidok-Olszewska, Warszawa 2007.

${ }^{2} \mathrm{~W}$ literaturze polskiej brak jest jednak odwołania do treści arabskich i muzułmańskich w tym zakresie. Na uwagę zasługują jedynie opracowania: Konstytucje państw arabskich, wybór, przekł. [z arab.] oraz wprow. N. H. Saleh, Warszawa 1992; S. Kitab, Wybrane zagadnienia klasycznego ustroju politycznego w islamie: skrypt dla studentów politologii, religioznawstwa oraz orientalistyki, Bydgoszcz 2004; H. A. Jamsheer, Reforma władzy $i$ społeczeństwa w arabsko-muzułmańskiej myśli politycznej wieków XIX i XX, Łódź 2008.

${ }^{3}$ Ministerstwo Spraw Zagranicznych w Warszawie, Biuro Archiwum i Zarządzania Informacją, Departament V, zespół 42/76, wiązka 7, teczka 24/2, strony 1-13: Plan pracy Departamentu V na rok 1973 r., załącznik - Systemy parlamentarne.

${ }^{4}$ Kompetencyjnie poszczególne departamenty w Ministerstwie nie odnosiły się do kontynentów, a raczej do określonych grup państw. W ten sposób w jednym dziale umiejscowiono kraje arabskie i Iran. W związku z tym, iż te pierwsze występowały na gruncie azjatyckim i afrykańskim, tak też wyodrębniono je w jedną całość. Jednocześnie 
Spośród regionu bliskowschodniego scharakteryzowano w załączniku tym systemy parlamentarne Libanu, Syrii i Jordanii, dalej Iraku, Kuwejtu i Iranu oraz Jemenu Północnego i Jemenu Południowego ${ }^{5}$. Przedmiotem omówienia parlamentaryzmów północnoafrykańskich stały się kraje Maghrebu - Maroko, Algieria i Tunezja oraz Maszreku - Egipt, Libia i Sudan.

Ze względu na stosunkowo słabe rozpoznanie parlamentaryzmów arabskich i muzułmańskich w tym okresie zdecydowano się na przedstawienie wspomnianego załącznika w całości. Niekiedy, jedynie takie dokumenty służą lepszemu zrozumieniu i poznaniu tak zawiłych kwestii, jak podstawy polityczno-ustrojowe państw. Jego treść zawarta została poniżej. W materiale nic nie zmieniono, a analityczne treści znalazły się w przypisach.

\section{Maroko}

Konstytucja zatwierdzona przez referendum w lipcu 1970 r. przewiduje jednoizbowy parlament (Izba Deputowanych), w skład którego wchodzi 240 deputowanych. Połowa tej liczby wybierana jest w głosowaniu powszechnym, 1/4 - przez kolegia elektorskie złożone z radnych miejskich i prowincjonalnych, pozostałą część stanowią wybrani członkowie izb handlowych, rolniczych i przemysłowych.

Do kompetencji parlamentu należy wydawanie ustaw, wypowiadanie wojny oraz zatwierdzanie przedłużenia stanu wyjątkowego na okres dłuższy niż 30 dni.

Tabela 1

Podzial mandatów w parlamencie wybranym w sierpniu 1970 r.

\begin{tabular}{||l|c||}
\hline \multicolumn{1}{|c|}{ Partia } & Ilość mandatów $^{-1}$ \\
\hline Niezależni $^{6}$ & 158 \\
\hline Movement populaire $^{7}$ & 60 \\
\hline Progres Social $^{8}$ & 10 \\
\hline Partia Niepodległości (Istiklal) $^{9}$ & 9 \\
\hline Union Nationale des Forces Populaires $^{10}$ & 2 \\
\hline Parti Democratique Constitutionel $^{11}$ & 1 \\
\hline
\end{tabular}

w przedmiotowym dziale nie ujęte zostały inne kraje muzułmańskie położone na kontynencie azjatyckim, które kompetencyjnie znalazły się już w gestii innego departamentu. Podobną sytuację możemy zaobserwować w strukturze organizacyjnej polskiego MSZ i współcześnie. Zob. Struktura organizacyjna MSZ, http://www.msz.gov.pl/Struktura,organizacyjna,MSZ,32554.html, 30.12.2011.

${ }^{5}$ Nie omówiono w dokumencie innych krajów arabskich w regionie, jak Arabia Saudyjska, Bahrajn, Katar, Oman i Zjednoczone Emiraty Arabskie. Ze zrozumiałych względów nie omówiono Państwa Izrael, które nie było powiązane religijnie $\mathrm{z}$ regionem.

${ }^{6} \mathrm{~W} 1978 \mathrm{r}$. grupa ta uległa instytucjonalizacji na skutek zorganizowania ruchu monarchistycznego pod nazwą Narodowego Zgromadzenia Niezależnych (Rassemblement national des indépendants).

${ }^{7}$ Chodzi o Marokański Ruch Ludowy. Socjalistyczna Unia Sił Ludowych w Maroku (Union socialiste des forces populaires) została założona w $1959 \mathrm{r}$.

${ }^{8}$ Chodzi o Partię Postępu Społecznego. Ugrupowanie to ulegało następnie licznym przemianom organizacyjnym i ideologicznym.

${ }^{9}$ Istiklal - to monarchistyczna Partia Niepodległości, powołana do życia w 1943 r. i należąca do najstarszych tego typu organizacji politycznych na terenie Maroka.

${ }^{10}$ Chodzi o Krajowy Związek Sił Ludowych. Związek ten podlegał następnie licznym modyfikacjom organizacyjnym i programowym.

${ }^{11}$ Chodzi o Demokratyczną Partię Konstytucyjną. Na przestrzeni kolejnych lat ruch ten zmieniał swe oblicze organizacyjne i ideologiczne. 
Przewodniczący Parlamentu Mahdi Ben Buszta.

Nowa forma parlamentu jest przewidziana przez konstytucję przyjętą przez referendum powszechne z marca 1972 r. Cała władza wykonawcza będzie powierzona parlamentowi i rządowi. Parlament będzie wybierany raz na 4 lata. 2/3 deputowanych będzie wybieranych w głosowaniu powszechnym, 1/3 - przez kolegia elektorskie ${ }^{12}$.

\section{Algieria}

Sprawy związane z parlamentem określone są w 27-36 art. konstytucji zaakceptowanej przez referendum ludowe we wrześniu 1963 r.

Prawo wyborcze przysługuje wszystkim obywatelom, którzy ukończyli 19 lat. Parlament wybierany jest w bezpośrednim i tajnym głosowaniu powszechnym. Jego kadencja trwa pięć lat. Parlament (Zgromadzenie Narodowe) sprawuje kontrolę nad rządem i, na równi z prezydentem państwa, posiada kompetencję występowania z inicjatywą ustaw. Parlament posiada 12 stałych komisji. Przewodniczący parlamentu jest drugą osobą w państwie po prezydencie.

Podczas ostatnich wyborów, które odbyły się w 1964 r. wybrano 138 deputowanych spośród kandydatów wyznaczonych przez $\mathrm{FLN}^{13}$.

Od tej pory, mimo kilkukrotnych zapowiedzi wybory do Zgromadzenia Narodowego nie odbyły się ${ }^{14}$.

\section{Tunezja}

W myśl konstytucji proklamowanej dnia 1 IV 1969 r. Zgromadzenie Narodowe posiada kompetencje legislacyjne. Jego kadencja wynosi 5 lat ${ }^{15}$.

Prawo głosu przysługuje każdemu, kto ukończył 20 lat i posiada obywatelstwo Tunezji nie mniej niż od 5 lat.

\footnotetext{
${ }^{12}$ Konstytucja ta uhonorowała w Maroku dziedziczną monarchię konstytucyjną. Wedle ustawy zasadniczej do króla oraz jednoizbowego parlamentu należała władza ustawodawcza. Władzę wykonawczą formalnie sprawował rząd z premierem na czele, ale powoływanym przez króla. Kadencja parlamentu ostatecznie określona została na 6 lat. Zob. A. Dziubiński, Historia Maroka, Wrocław 1983, s. 429 i n.

${ }^{13}$ FLN (właściwie FWN) - Front Wyzwolenia Narodowego (Dżabhat at-Tahrir al-Watanijja). Ta algierska organizacja niepodległościowa została zainicjowana w 1954 r. na fali kształtowania ruchu, mającego doprowadzić do uniezależnienia się departamentów algierskich od Francji. W latach 1963-1990 pozostawała jedyną legalną partią, kierującą życiem politycznym Algierii, zorganizowaną od 1965 r. na zasadach centralizmu wewnątrzpartyjnego z silną władzą przewodniczącego. Zob. A. Kasznik-Christian, Wojna algierska 1954-1962: u źródeł niepodległej państwowości, Łódź 2001; tejże, Algieria, Warszawa 2006, s. 365 i n.

${ }^{14}$ Partia rządząca pozostawała u władzy w Algierii aż do 1989 r., kiedy to zadecydowała o stworzeniu podstaw systemu wielopartyjnego w tym kraju. Wobec nadmiernego wzrostu poparcia społecznego dla islamskich fundamentalistów skupionych we Froncie Ocalenia Narodowego (FIS) nie zdecydowano się na pełną demokratyzację systemu. W wyniku przeprowadzonych wyborów do rad municypalnych w 1990 r. islamski front zdystansował dotychczasowego hegemona, zdobywając ponad połowę głosów. Kiedy sytuacja taka powtórzyła się w grudniu $1991 \mathrm{r}$. po pierwszej turze wyborów parlamentarnych, dotychczasowe władze, nie chcąc doprowadzić do powstania islamskiego państwa wyznaniowego na wzór Iranu, zawiesiły proces demokratyzacji i zdecydowały się na rządy autorytarne, popierane zresztą przez państwa europejskie. Zob. A. Antoszewski, R. Herbut, Systemy polityczne współczesnego świata, Gdańsk 2001, s. 41.

15 Zob. A. Dziubiński, Historia Tunezji, Wrocław 1994, s. 312-315.
} 
Zgromadzenie Narodowe zbiera się co najmniej dwa razy do roku. Sesja nie może trwać dłużej niż trzy miesiące. Dodatkowe sesje mogą być zwoływane przez prezydenta lub na wniosek większości deputowanych.

Ostatnie wybory - listopad $1969 \mathrm{r}$.

Wszystkie 101 mandatów przypadło w udziale kandydatom rządzącej Socjalistycznej Partii Desturiańskiej (PSD).

Przewodniczący ZN Sadok Mokaddem ${ }^{16}$.

I-szy V-Przewodniczący Ferdżani Belhadż Ammar ${ }^{17}$.

\section{Egipt}

Rada Ludowa (zgodnie z Konstytucją wybierana na okres 5 lat) ${ }^{18}$. Wybory 27 X i 3 XI 1971 r. 360 deputowanych: 53\% - chłopi i robotnicy, przewodniczący - Hafez Badawi.

\section{Irak}

Od rewolucji 1958 r., która obaliła monarchię, w Iraku nie istniały żadne formy Zgromadzenia Narodowego. Obecna tymczasowa konstytucja zawiera punkty mówiące o wyborze nowego zgromadzenia (składającego się ze 100 członków) w terminie, który określi rząd iracki.

Tymczasowa konstytucja, ogłoszona 22 IX 1968 r. stwierdza, że do czasu wyboru Zgromadzenia Narodowego najwyższą władzą w państwie jest Rada Dowództwa Rewolucji, która promulguje ustawy ${ }^{19} .5$ członków Rady Dowództwa Rewolucji są mianowani wiceprezydentami państwa.

${ }^{16}$ Sadok Mokaddem (1914-1993) - lekarz i polityk tunezyjski. Od 1950 r. związany z polityczną frakcją Neo-Destur, za co został aresztowany przez francuskie władze administracyjne. W 1955 r. nominowany na ministra zdrowia w drugim rządzie Tahar Ben Ammar. Po uzyskaniu przez Tunezję pełnej niepodległości wybrano go do Zgromadzenia Narodowego Konstytucyjnego oraz mianowano ambasadorem w Egipcie. W latach 1957-1962 pełnił odpowiedzialne stanowisko ministra spraw zagranicznych. W 1964 r. wybrany na przewodniczącego Zgromadzenia Narodowego, które to stanowisko piastował do 1981 r. Po śmierci został patronem głównego szpitala na jego rodzinnej wyspie Dżerba. Jedną z głównych ulic Tunisu w 2011 r. także nazwano jego imieniem. Zob. Sadok Mokaddem, http://fr.wikipedia.org/wiki, 30.12.2011.

${ }^{17}$ Ferdżani Belhadż Ammar (właśc. Ferjani Bel Haj Ammar) - polityk tunezyjski. W okresie od 31 października 1972 do 5 czerwca 1973 r. był dyrektorem rządzącej Socjalistycznej Partii Desturiańskiej (PSD). Partia ta powstała w 1964 r., dzięki inicjatywie prezydenta kraju Habiba Bourguiby, i stała się formalnym następcą ruchu Neo-Destur. Zob. A. Belkhodja, Les trois décennies Bourguiba. Témoignage, Paris 1998; A. Ellyas, B. Stora, Les 100 portes du Maghreb: l'Algérie, le Maroc, la Tunisie. Trois voies singulières pour allier islam et modernité, Paris 1999, p. 35.

${ }^{18}$ Konstytucja z 1971 r. podkreślała republikański porządek w państwie. Na jego czele stał prezydent wybierany w głosowaniu powszechnym na 6-letnią kadencję i mający szerokie uprawnienia w zakresie władzy ustawodawczej oraz wykonawczej. Przy głowie państwa występowała jedynie Rada Prezydencka mająca charakter doradczy. Powoływany przez głowę państwa był także rząd, przy boku którego występowała 258-osobowa Rada Konsultatywna. Zob. A. L. al-Sayyid Marsot, A Short History of Modern Egypt, Cambridge 1993.

${ }^{19}$ Według tymczasowej konstytucji z 1968 r., następnie modyfikowanej w 1973 i 1974 r. Irak miał być republiką o charakterze ludowo-demokratycznym, której porządek ekonomiczny opierał się na zasadach socjalistycznych, a religią dominującą był islam. W myśl tych założeń najwyższym organem władzy państwowej była kilkuosobowa Rada Dowództwa Rewolucji, wybierana spośród członków irackiego kierownictwa partii Bass. Głową państwa był prezydent wybierany przez tę Radę, jednocześnie pozostawał jej przewodniczącym i pełnił realną władzę w wojsku pozostając naczelnym dowódcą sił zbrojnych. Zob. H. Obeidat, Stosunki Polski z Egiptem i Irakiem w latach 1955-1989, Toruń 2001, s. 23. 
Listopad 1969 - 2 poprawki do konstytucji. Ilość członków Rady Dowództwa Rewolucji miała wzrosnąć do więcej niż 5 - według uznania prezydenta.

Lipiec 1970 - nowa tymczasowa konstytucja, której jeden z artykułów dał bliższą definicję Rady Dowództwa Rewolucji. Obecnie składa się ona z 12 członków - wszyscy członkowie rządzącej partii Baas.

Listopad 1971 - prezydent Bakr ${ }^{20}$ ogłosił Kartę Narodową jako pierwszy krok w kierunku opracowania stałej konstytucji. W Karcie Zgromadzeniu Narodowemu udziela się dużo uwagi.

\section{Arabska Republika Jemenu ${ }^{21}$}

Rada Konsultatywna - utworzona jako najwyższe ciało ustawodawcze konstytucją w 1970 r. Składa się ze 179 członków, 20 z nich naznacza prezydent. Pozostali są wybierani w głosowaniu ludowym co 4 lata. Pierwsze wybory odbyły się w marcu 1971 r. Przewodniczący Rady konsultatywnej - Abd Allah ibn Hasan al Ahmar.

\section{Ludowo-Demokratyczna Republika Jemenu Południowego ${ }^{22}$}

Według konstytucji z 30 XI 1970 r. władza ustawodawcza należała do Tymczasowej Najwyższej Rady Ludowej, do której zostało wybranych 101 członków, głównie z Narodowego Frontu Wyzwolenia. 15 robotników wybrały związki zawodowe.

Zgodnie z porozumieniem zawartym $29 \mathrm{X}$ br. w Kairze, dotyczącym zjednoczenia obu państw jemeńskich, na konferencji na szczycie przywódców obu państw, która odbędzie się 25 XI br. ma zostać m.in. powołany Komitet do spraw Ustawodawstwa i Sądownictwa. Komitet ten ma zająć się unifikacją systemów parlamentarnych w obu krajach. Rady Ustawodawcze mają być rozwiązane po przyjęciu nowej konstytucji i utworzone ma być jedno wspólne ciało ustawodawcze $\mathrm{e}^{23}$.

${ }^{20}$ Ahmed Hassan al-Bakr (właśc. Ahmad Hasan al-Bakr) (1914-1982) - polityk iracki. W okresie młodości należał do czołowych działaczy w irackim oddziale partii Baas, w której głosił potrzebę połączenia arabskiego socjalizmu z arabskim nacjonalizmem. Jego znaczenie wzrosło po rewolucji z 1958 r., która obaliła monarchię. Przejściowo popadł w niełaskę głównego orędownika puczu, ale kiedy w lipcu 1968 r. członkowie partii Baas dokonali przewrotu politycznego, stanął na czele państwa. W lipcu 1979 r. ustapił z najwyższych stanowisk państwowych na rzecz swojego krewnego Saddama Husajna, którego także oskarżano o przyczynienie się do przedwczesnej jego śmierci. Zob. M. M. Dziekan, Historia Iraku, wyd. 2, Warszawa 2007.

${ }^{21}$ Państwo to zajmowało obszar Północnego Jemenu, który w przeszłości nie posiadał zbyt dużych więzów z ziemiami Południowego Jemenu. Jemen Północny stał się państwem na wskroś niepodległym w wyniku zakończenia okupacji tureckiej i zakończenia I wojny światowej. Po II wojnie światowej Jemen Północny współtworzył ONZ i Ligę Państw Arabskich. Stopniowo prowadził coraz bardziej otwartą politykę na świat zewnętrzny. Po śmierci imama Ahmada w 1962 r. władzę przejęła armia, ogłaszając powołanie republiki. Jednocześnie rozpoczęły się w kraju tym walki wewnętrzne między ruchem republikańskim i monarchistycznym. Stopniowo przerodziły się one w walki z sąsiadującym Jemenem Południowym. Postfeudalna struktura społeczna miała także wpływ na formowanie parlamentu. Zob. N. H. Saleh, Jemen: jedno serce - jeden naród, Warszawa 1994.

${ }^{22}$ W odróżnieniu do północnych obszarów Jemenu, część południowa stała się stosunkowo szybko terytorium o wzmożonym zainteresowaniu kolonizatorów europejskich. Już w 1839 r. Brytyjczycy zdobyli Aden, poszerzając stopniowo swe wpływy w regionie. Obszar ten uzyskał strategiczne znaczenie po 1869 r., kiedy otwarto Kanał Sueski, co zdopingowało Brytyjczyków do utworzenia Protektoratu Adenu. W kilku konfiguracjach terytorialnych pozostał on pod wpływami Wielkiej Brytanii do 1967 r., kiedy to uzyskał podmiotowość międzynarodową. Wedle konstytucji z 1970 r. miała to być Ludowo-Demokratyczna Republika Jemenu. Por. ibidem.

${ }^{23}$ Ostatecznie do utworzenia jednego państwa jemeńskiego nie doszło. Zbrojne potyczki graniczne między Jemenem Południowym a Jemenem Północnym prowadzone na początku lat 70. XX w. przerodziły się w otwartą woj- 


\section{Liban}

Parlament jednoizbowy - Izba Deputowanych wybierana na okres 4 lat. 99 członków: 54 - chrześcijanie, 45 - muzułmanie.

Tajne głosowanie zostało wprowadzone w nowym prawie wyborczym w kwietniu $1960 \mathrm{r}$. Reforma wyborcza z 1960 r. utrzymała istniejący stosunek 6 chrześcijan na 5 muzułmanów.

Przewodniczący Izby Deputowanych - Kamal Asaad ${ }^{24}$, wiceprzewodniczący - Nasim Majdalani ${ }^{25}$.

Tabela 2

Grypy religijne w parlamencie

\begin{tabular}{||l|c|}
\hline \multicolumn{1}{|c|}{ Grupy religijne } & Liczba deputowanych \\
\hline Maronite Christians $^{26}$ & 30 \\
\hline Sunni Muslims & 27 \\
\hline Shií Muslims $^{28}$ & 20 \\
\hline Greek Ortodo $^{29}$ & 19 \\
\hline Greek Catholics $^{30}$ & 11 \\
\hline Druses $^{31}$ & 6 \\
\hline Armenian Ortodox $^{32}$ & 6 \\
\hline Armenian Catholics $^{33}$ & 4 \\
\hline Protestants $^{34}$ & 1 \\
\hline Inni & \\
\hline Razem: & 1 \\
\hline
\end{tabular}

W maju br. odbyły się wybory powszechne lecz różnorodność powiązań partyjnych w Izbie Deputowanych uniemożliwia adekwatną analizę ugrupowań partyjnych. Podział miejsc w Izbie Deputowanych między grupami religijnymi jest określony przez prawo ${ }^{36}$.

nę, która została przerwana na skutek mediacji innych państw arabskich. Do powstania jednego państwa jemeńskiego doszło dopiero w 1994 r. Por. ibidem.

${ }^{24}$ Kamel El Assaad lub Kamel Al Assaad (1932-2010) - polityk libański. Pochodził z szanowanej szyickiej rodziny wywodzącej się z południa Libanu, dzięki czemu uzyskał mandat parlamentarny. W latach 1964-1984 kilkakrotnie pełnił obowiązki przewodniczącego libańskiego parlamentu. Po 1984 r. przyjął kurs bardziej lewicowy, stając na czele Libańskiej Partii Socjaldemokratycznej. Mimo zabiegów nie udało mu się wygrać wyborów parlamentarnych, przez co w ostatnich latach działalności pozostawał nieco w cieniu życia politycznego Bliskiego Wschodu. Por. Kamel Asaad, http://en.wikipedia.org/wiki, 30.12.2011.

${ }^{25} \mathrm{Na}$ temat roli Nasima Majdalaniego w życiu politycznym Libanu zob. J. P. Entelis, Pluralism and party transformation in Lebanon, bmw. 1974, s. 135.

${ }^{26}$ Przedstawiciele Kościoła maronickiego.

${ }^{27}$ Przedstawiciele muzułmańskich sunnitów.

${ }^{28}$ Przedstawiciele muzułmańskich szyitów.

${ }^{29}$ Przedstawiciele greckiego Kościoła prawosławnego.

${ }^{30}$ Przedstawiciele greckiego Kościoła katolickiego.

${ }^{31}$ Przedstawiciele Druzów, ugrupowania religijnego, które powstało na bazie ruchu ismailitów.

32 Przedstawiciele Kościoła ormiańskiego.

${ }^{33}$ Ormiańscy przedstawiciele Kościoła katolickiego, tzw. ormiańscy unici.

${ }^{34}$ Przedstawiciele Kościoła protestanckiego.

${ }^{35}$ Liban był typowym tyglem narodowościowym i religijnym na Bliskim Wschodzie, do którego na przestrzeni wieków przybywali także przedstawiciele judaizmu, hinduizmu, sikhizmu czy buddyzmu.

${ }^{36}$ Wedle założeń przyjętych w 1943 r. ustalono klucz wyznaniowy, wedle którego obsadzane były stanowiska państwowe i rządowe w Libanie. Wynikało z nich, iż stanowisko prezydenta miał obsadzać chrześcijanin maronita, 


\section{Syria}

Rada Ludowa - powołana 16 II 1971 r. przez Regionalne Dowództwo partii Baas na okres 2 lat. Liczy 173 członków. Rada Ludowa jest wybierana przez Regionalne Dowództwo partii Baas, która w jej składzie posiada 87 swych przedstawicieli. W Radzie Ludowej oprócz przedstawicieli partii Baas zasiadają przedstawiciele 11 innych partii i ugrupowań (w tym przedstawicieli KP Syrii). Zadaniem Rady Ludowej jest wypracowanie stałej konstytucji, wybór kandydata na prezydenta spośród Regionalnego Dowództwa partii Baas. Rada Ludowa bierze także udział w dyskusji na temat polityki rządu i może wycofać swe poparcie dla dowolnego gabinetu czy ministra ${ }^{37}$.

Partyjna struktura Rady Ludowej

Tabela 3

\begin{tabular}{|c|c|}
\hline Partia & Ilość miejsc \\
\hline Partia Baas ${ }^{38}$ & 87 \\
\hline Syryjski AZS ${ }^{39}$ & 11 \\
\hline KP Syrii ${ }^{40}$ & 8 \\
\hline Niezależni Postępowcy & 7 \\
\hline Niezależni Baasiści & 5 \\
\hline Związek Socjalistyczny & 4 \\
\hline Syryjska Partia Socjalistyczna & 4 \\
\hline Byli Baasiści & 3 \\
\hline Niezależni Naserowcy & 2 \\
\hline Muslims religious leaders $^{41}$ & 3 \\
\hline Businessman $^{42}$ & 3 \\
\hline General Union of Farmers ${ }^{43}$ & 36 \\
\hline Razem (włączając 4 kobiety) & 173 \\
\hline
\end{tabular}

Przewodniczący: Fahmi Al-Yousfi.

Wiceprzewodniczący: Adham Mustafa.

stanowisko premiera muzułmanin sunnita, a funkcję przewodniczącego parlamentu muzułmanin szyita. Zob. E. Rekłajtis, Liban, Warszawa 1993.

${ }^{37}$ Wedle konstytucji przyjętej w 1973 r. na czele państwa syryjskiego stanął prezydent, wybierany na 7-letnią kadencję przez parlament na wniosek kierownictwa partii Baas i zatwierdzany w drodze powszechnego referendum. Najwyższym organem ustawodawczym pozostał 1-izbowy parlament, składający się z 250 posłów i wybierany w głosowaniu powszechnym na 4-letnią kadencję. Na czele egzekutywy stał rząd na czele z premierem, wskazywanym jednak przez prezydenta. Zob. J. Skuratowicz, W. Skuratowicz, Przemiany wewnętrzne i polityka zagraniczna Syrii, Warszawa 1974.

${ }^{38}$ Odłam syryjski Partii Socjalistycznego Odrodzenia Arabskiego. Partia Baas powstała w 1953 r. z połączenia Partii Odrodzenia Arabskiego oraz syryjskiej Arabskiej Partii Socjalistycznej. Głosiła hasła jedności, wolności i socjalizmu w świecie arabskim. W wyniku kryzysu wewnętrznego w 1966 r. powstały dwa zwalczające się odłamy tego ugrupowania z siedzibą w syryjskim Damaszku i irackim Bagdadzie. Zob. Z. M. Kowalewski, Szwadrony śmierci Armii Mahdiego sieja terror wyznaniowy w Iraku: polaryzacja ruchu oporu między takfirytami a basistami, „Le Monde Diplomatique" (ed. polska) 2007, nr 2, s. 4-5.

${ }^{39}$ Syryjski Arabski Związek Socjalistyczny.

${ }^{40}$ Syryjska Partia Komunistyczna.

${ }^{41}$ Przywódcy i reprezentanci muzułmańskich grup religijnych.

42 Przedstawiciele syryjskiej organizacji, skupiającej biznesmenów i przedsiębiorców.

${ }^{43}$ Reprezentanci własności ziemskiej i grup etnograficznych. 


\section{Libia}

Senat i Izba Reprezentantów zostały rozwiązane po przewrocie we wrześniu 1969 r. Tymczasowa konstytucja ogłoszona w grudniu 1969 r. nic nie mówiła o wyborach lub o nawrocie do systemu parlamentarnego.

W styczniu 1971 r. pułk. Kadafi ogłosił, że nowy parlament będzie naznaczony a nie wybrany. Data nie została podana. Oprócz libijskiego AZS-u partie polityczne są zakazane ${ }^{44}$.

\section{Sudan}

Zgodnie z tymczasową konstytucją z sierpnia 1971 r. dla opracowania stałej konstytucji zostanie powołane Zgromadzenie Ludowe.

Regionalna konstytucja dla Południowego Sudanu przewiduje utworzenie regionalnego Zgromadzenia Ludowego dla Południa. Według tymczasowej konstytucji w centralnym Zgromadzeniu Ludowym Południowy Sudan będzie w odpowiedniej proporcji reprezentowany ${ }^{45}$.

\section{Jordania}

Władza ustawodawcza należy do Zgromadzenia Narodowego i króla ${ }^{46}$. Zgromadzenie Narodowe składa się z 2 izb:

Senat - liczy 30 członków naznaczanych przez króla na okres 4 lat. Zgodnie z konstytucją senatorzy nie mogą być krewnymi króla, muszą mieć powyżej 40 lat i nie mogą piastować urzędów publicznych. Senatorzy są naznaczani z liczby obecnych i byłych premierów, ministrów, byłych ambasadorów, przewodniczących Izby Reprezentantów, byłych przewodniczących i członków Sądu Kasacyjnego, poprzednich członków Izby Reprezentantów wybieranych do niej dwukrotnie itd. Senatorzy mogą być wybrani przez króla na okres następnych 4 lat. Przewodniczący Senatu jest naznaczany na okres 2 lat. Przewodniczący Senatu: Said Al Mufti ${ }^{47}$.

${ }^{44}$ Konstytucja tego kraju została przyjęta dopiero w 1977 r. Wedle jej założeń władza ustawodawcza należała do 178 lokalnych zgromadzeń i komitetów ludowych, a nadrzędnym organem ustawodawczym był Powszechny Kongres Ludowy. W miejsce instytucji głowy państwa powołano 5-osobowy Sekretariat Generalny Kongresu, a w miejsce rządu Generalny Komitet Ludowy Kongresu. W praktyce rządy autorytarne sprawował płk. Muammar al-Kaddafi z oficjalnym tytułem Przywódcy Rewolucji 1 Września. Zob. M. Al Qadhafi, Myśli: wybrane z Zielonej Ksiqżki, Kraków 1991.

${ }^{45}$ Republika Sudanu od uzyskania w 1956 r. niepodległości borykała się z problemami natury polityczno-etnicznej i polityczno-religijnej między Północą i Południem kraju. Po zamachu stanu z 1969 r., kiedy to na czele państwa stanął gen. Dż. an-Numajri, zawarto porozumienie między poszczególnymi prowincjami, czego owocem było uzyskanie autonomii przez trzy prowincje skupione na Południu kraju. W 1976 r. doszło jednak do kolejnej destabilizacji sytuacji w kraju, w wyniku czego doszło do pogłębienia podziałów religijnych i etnicznych oraz nasilenia się walk zbrojnych. Zob. J. Bury, Polityka wybranych państw arabskich wobec krajów Afryki subsaharyjskiej, w: Stosunki międzynarodowe w Afryce, red. J. J. Milewski, W. Lizak, Warszawa 2002, s. 297 i n.

${ }^{46}$ W Jordanii dominował system monarchiczny, z osobą króla na czele.

47 Said Pasza al-Mufti (1898-1989) - polityk jordański pochodzenia czerkieskiego. Przyczynił się do powstania opozycji antytureckiej na Bliskim Wschodzie, dzięki czemu piastował później ważne funkcje publiczne i państwowe, m.in. trzykrotnie występował jako premier tego kraju. Zob. http://www.visitjordan.com/visitjordan_cms/Default.aspx?tabid=292, 30.12.2011. 
Izba Reprezentantów - liczy 60 członków wybieranych na okres 4 lat w głosowaniu tajnym w wyborach powszechnych i bezpośrednich. Przewodniczący Izby jest wybierany przez członków Izby Reprezentantów w głosowaniu tajnym każdego roku. Członkowie Izby muszą być obywatelami jordańskimi powyżej 30 lat, mieć nieskazitelną przeszłość, nie prowadzić aktywnej działalności handlowej, nie piastować urzędów publicznych. Bliscy krewni króla są niewybieralni. Przewodniczący Izby Reprezentantów - Kamil Arikat ${ }^{48}$.

\section{Iran}

Parlament, którego kadencja wynosi 4 lata, składa się z 2 izb ${ }^{49}$ :

Senat - liczy 60 członków; 30 z nich naznacza szach, 30 jest wybieranych ( 15 z Teheranu, 15 z prowincji). Senatorzy muszą być muzułmanami.

Doradcze Zgromadzenie Narodowe - Medżlis. Liczy ponad 200 członków wybieranych na okres 4 lat. Ilość członków Zgromadzenia wzrasta wraz ze wzrostem liczby ludności. Wybory na 23 sesję Medżlisu odbyły się w lipcu $1971 \mathrm{r}$.

Tabela 4

Wybory w lipcu 1971 r.

\begin{tabular}{|c|c|c|}
\hline Partia & Senat & Medżlis \\
\hline Iran Novin Party ${ }^{50}$ & 26 & 228 \\
\hline Mardom Party ${ }^{51}$ & 9 & 36 \\
\hline Independent $^{52}$ & 24 & 2 \\
\hline Vacant $^{53}$ & 1 & 2 \\
\hline Razem & 60 & 268 \\
\hline
\end{tabular}

Przewodniczący Senatu - inż. Ja`afar Sharif-Emami ${ }^{54}$.

Przewodniczący Doradczego Zgromadzenia Narodowego - inż. A. Riazi.

\section{Kuwejt}

Zgromadzenie Narodowe - kadencja 4 lata; 50 członków. Kandydaci na wybór w poczet członków Zgromadzenia Narodowego powinni posiadać prawa obywatelskie i mieć ukończo-

${ }^{48}$ Zob. List of Parliamentary Speakers in Asia in 1970, http://en.wikipedia.org/wiki/List_of_Parliamentary_Speakers_in_Asia_in_1970, 30.12.2011.

${ }^{49}$ Iran był wówczas systemem monarchicznym, a decydującą rolę w państwie odgrywał szach Mohammad Reza Pahlawi.

${ }^{50}$ Dominująca partia irańska, będąca przybudówką i ostoją władzy szacha.

${ }^{51}$ Główna partia opozycyjna ówczesnego Iranu, której założycielem był Amir Asadollah Alam, właściciel ziemski, były premier i bliski współpracownik oraz powiernik szacha. Ranga partii wzrosła po 1975 r., kiedy nasiliła się presja demokratyzacji systemu. Zob. Mardom party, http://www.answers.com, 30.12.2011.

${ }^{52}$ Kandydaci niezależni.

${ }^{53}$ Miejsca do wypełnienia.

${ }^{54}$ Właśc. Jafar Sharif-Imami (1910-1998) - polityk irański. Był jednym z zaufanych ludzi szacha Mohammada Rezy Pahlawiego. W związku z tym pełnił odpowiedzialne funkcje państwowe-był ministrem, prezydentem Senatu, prezesem Fundacji Pahlavi, prezesem Irańskiej Izby Przemysłu i Górnictwa oraz dwukrotnie premierem. Zob. Jafar Sharif-Emami, http://en.wikipedia.org, 30.12.2011. 
ne 30 lat. W wyborach 23 I 1971 r. zostało mianowanych 184 kandydatów na 50 miejsc (5 miejsc w każdym z 10 regionów).

Nie ma oficjalnych partii politycznych, kandydaci występują indywidualnie. Mimo to w wyborach 1971 r. 5 członków radykalnego Arabskiego Ruchu Nacjonalistycznego zostało wybranych. Z czynnego prawa wyborczego mogą korzystać tylko mężczyźni - rodowici Kuwejtczycy, którzy ukończyli 21 lat, umiejący czytać i pisać (w Kuwejcie około 40000 wyborców $)^{55}$. Sekretarz Zgromadzenia Narodowego - Sami Al-Maneisy.

$* * *$

Trzeba zaznaczyć, że załącznik przygotowany przez Departament V polskiego MSZ został zredagowany w sposób kompetentny, zarówno pod względem treści, jak też i zgromadzonych faktów. Osoba przygotowująca miała dobre przygotowanie merytoryczne oraz rozeznanie empiryczne zarówno w tematyce północnoafrykańskiej i bliskowschodniej, jak też i polityczno-ustrojowe. Ważnym elementem każdego z charakteryzowanych państw było wskazanie na osobę bądź osoby, które zajmowały w systemach parlamentarnych krajów arabskich i muzułmańskich eksponowane miejsca. Takie usytuowanie osobowości tych w dokumencie tym dawało polskim służbom dyplomatycznym działającym na Bliskim Wschodzie i Afryce Północnej odpowiednią pomoc i rozeznanie polityczne. Wiedziały one do kogo personalnie się zwrócić, aby promować polskie potrzeby i interesy. To samo dotyczyło ugrupowań partyjnych oraz ich reprezentantów.

Odpowiednio przygotowane rozmowy polityczne mogłyby następnie skutkować nawiązaniem współpracy gospodarczej, wymianą towarową, eksportem polskich usług, kadr naukowo-technicznych, kompletnych obiektów przemysłowych czy importem ropy naftowej oraz innych surowców. W szczególności ta ostatnia kwestia była dyskutowana i rozważana, co miało zabezpieczyć polski przemysł na dostawy tego surowca z innych rynków aniżeli radziecki. Kopaliny takie z kolei można było pozyskać jedynie w drodze rozmów i negocjacji międzypaństwowych.

Należy jednoznacznie stwierdzić, że publikowany materiał MSZ z pewnością mógł wpłynąć na treść przedsięwzięć politycznych, jakie strona polska chciała artykułować względem krajów arabskich i muzułmańskich. Przełom lat 60. i 70. XX w. w sposób poważny zmienił oblicze środowiska międzynarodowego na wybrzeżach Morza Śródziemnego. W okresie tym doszło do puchów wojskowych i zamachów stanu (Libia, Egipt, Sudan, Syria, Irak), zmian systemowych (Jemen Południowy, Algieria) czy wyodrębnienia się niektórych jednostek państwowych (Bahrajn, Katar, Oman, Zjednoczone Emiraty Arabskie). Przez cały czas skomplikowana była sytuacja wokół polityki Izraela, który pozostawał w silnej konfrontacji z państwami arabskimi. To właśnie ta ostatnia kwestia spowodowała, że trudno było mówić o zrealizowaniu podmiotowych i przedmiotowych celów strategicznych polskiej polityki zagranicznej względem Bliskiego Wschodu i Afryki Północnej. To przede wszystkim kolejna wojna izraelsko-arabska z października 1973 r. unaoczniła polskim decydentom, jak kruche są w regionie podstawy państwowe, które uniemożliwiać miały pełne zaangażowanie się Polski w krajach arabskich i muzułmańskich.

\footnotetext{
55 Według konstytucji nadanej przez panującego w 1962 r. Kuwejt był dziedziczną monarchią, na której czele stał emir z panującego rodu As-Sabah. Zob. G. Kończyk, J. Zdanowski, Zarys historii i przemian społeczno-ekonomicznych Kuwejtu, Wrocław 1989; R. Bania, Kuwejt w polityce Wielkiej Brytanii w latach 1958-1968, Łódź 2009.
} 


\section{Bibliografia}

Antoszewski A., Herbut R., Systemy polityczne wspótczesnego świata, Gdańsk 2001.

Antoszewski A., Herbut R., Systemy polityczne wspótczesnej Europy, Warszawa 2006.

Balicki R., Ustroje państw współczesnych, Wrocław 2003.

Bania R., Kuwejt w polityce Wielkiej Brytanii w latach 1958-1968, Łódź 2009.

Bankowicz M., Tkaczyński J., Oblicza współczesnego państwa, Toruń 2003.

Baszkiewicz J., Powszechna historia ustrojów państwowych, Gdańsk 1998.

Belkhodja A., Les trois décennies Bourguiba. Témoignage, Paris 1998.

Deszczyński P., Gołata K., Demokratyczne systemy i doktryny polityczne, Poznań 2003.

Dziekan M. M., Historia Iraku, wyd. 2, Warszawa 2007.

Dziubiński A., Historia Maroka, Wrocław 1983.

Dziubiński A., Historia Tunezji, Wrocław 1994.

Ellyas A., Stora B., Les 100 portes du Maghreb: l'Algérie, le Maroc, la Tunisie. Trois voies singulières pour allier islam et modernité, Paris 1999.

Entelis J. P., Pluralism and party transformation in Lebanon, bmw. 1974.

Gulczyński M., Panorama systemów politycznych świata, Warszawa 2004.

Jafar Sharif-Emami, http://en.wikipedia.org.

Jamsheer H. A., Reforma władzy i społeczeństwa w arabsko-muzulmańskiej myśli politycznej wieków XIX i XX, Łódź 2008.

Kamel Asaad, http://en.wikipedia.org/wiki.

Kasznik-Christian A., Wojna algierska 1954-1962: u źródet niepodległej państwowości, Łódź 2001.

Kasznik-Christian A., Algieria, Warszawa 2006.

Kitab S., Wybrane zagadnienia klasycznego ustroju politycznego w islamie: skrypt dla studentów politologii, religioznawstwa oraz orientalistyki, Bydgoszcz 2004.

Knopek J. (oprac.), Współczesne systemy polityczne w wypisach, Bydgoszcz 2001.

Konstytucje państw arabskich, wybór, przekł. [z arab.] oraz wprow. N. H. Saleh, Warszawa 1992.

Kończyk G., Zdanowski J., Zarys historii i przemian społeczno-ekonomicznych Kuwejtu, Wrocław 1989.

Kowalewski Z. M., Szwadrony śmierci Armii Mahdiego sieja terror wyznaniowy w Iraku: polaryzacja ruchu oporu między takfirytami a basistami, „Le Monde Diplomatique” (ed. polska) 2007, nr 2.

List of Parliamentary Speakers in Asia in 1970, http://en.wikipedia.org/wiki/List_of_Parliamentary_Speakers_in_Asia_in_1970.

Mardom party, http://www.answers.com.

Ministerstwo Spraw Zagranicznych w Warszawie, Biuro Archiwum i Zarządzania Informacją, Departament V, zespół 42/76, wiązka 7, teczka 24/2.

Obeidat H., Stosunki Polski z Egiptem i Irakiem w latach 1955-1989, Toruń 2001.

Qadhafi M. Al., Myśli: wybrane z Zielonej Ksiqżki, Kraków 1991.

Rekłajtis E., Liban, Warszawa 1993.

Sadok Mokaddem, http://fr.wikipedia.org/wiki.

Saleh N. H., Jemen: jedno serce - jeden naród, Warszawa 1994.

Sarnecki P., Ustroje konstytucyjne państw współczesnych, Kraków 2003.

al-Sayyid Marsot A. L., A Short History of Modern Egypt, Cambridge 1993.

Skuratowicz J., Skuratowicz W., Przemiany wewnętrzne i polityka zagraniczna Syrii, Warszawa 1974.

Stosunki międzynarodowe w Afryce, red. J. J. Milewski, W. Lizak, Warszawa 2002.

Struktura organizacyjna MSZ, http:/www.msz.gov.pl/Struktura,organizacyjna,MSZ,32554.html.

Współczesne systemy polityczne, red. M. Żmigrodzki, B. Dziemidok-Olszewska, Warszawa 2007. 


\title{
Parliamentary systems of selected Arab and Muslim states as presented in a memo for executives in the Ministry of Foreign Affairs in 1972
}

\begin{abstract}
Summary
The paper discusses the parliamentary systems of selected Arab and Muslim countries in the Middle East and North Africa at the turn of the 1960s. The analysis concerns a document drawn up for executives in the Ministry of Foreign Affairs in late 1972, with an attachment discussing the parliamentary systems of the countries of primary importance for the goals and interests of Poland. As concerns the Middle East, the parliamentary systems of Lebanon, Syria, Jordan, Iraq, Kuwait, Iran and North and South Yemen were described. In North Africa, the analysis encompassed the Maghreb region: Morocco, Algeria, Tunisia, and the Mashrek region: Egypt, Libya and Sudan. The paper concludes with a statement that the document was an accurate and faithful presentation of the parliamentary systems of representative states. Political relations in this region were developing dynamically at that time, military coups and coups d'état occurred, some states were leaning towards socialism, while maintaining their family or religious structures, while others were only just gaining their full sovereignty and independence. The situation of Israel continued to be complicated, as the state remained highly confrontational towards Arab countries. This last issue was the reason for Poland's failing to achieve the strategic goals of its foreign policy in the Middle East and North Africa. Another Israeli-Arab war in October 1973 made Polish decision makers realize how fragile the foundations of states in the region were, preventing Poland from becoming fully involved in Arab and Muslim countries.
\end{abstract}

